\title{
ОЦІНКА РІВНЯ ТА СТРУКТУРИ ЗАХВОРЮВАНОСТІ СТУДЕНТІВ ЗАКАРПАТСЬКОГО БАЗОВОГО ДЕРЖАВНОГО МЕДИЧНОГО КОЛЕДЖУ
}

\author{
Т. М. Томишин, Н. І. Рега, С. О. Ястремська \\ Хустська районна лікарня \\ ДВНз «Тернопільський державний медичний університет \\ імені І. Я. Горбачевського МОЗ Украӥни"
}

\begin{abstract}
У статті розкрито структуру та частоту захворюваності студентів медичного коледжу, наведено результати аналізу і класифікацію захворювань. Встановлено, що головною причиною великої кількості захворювань $є$ низький рівень рухової активності студентської молоді, а також фізичного розвитку та фізичної підготовленості. Представлено заходи для активізації навчального процесу в медичному коледжі. Розкрито перспективи впровадження подальших просвітницько-навчальних та охоронних технологій навчання.
\end{abstract}

\section{EVALUATION OF THE MORBIDITY LEVEL AND STRUCTURE OF STUDENTS OF TRANSCARPATHIAN BASIC STATE MEDICAL COLLEGE}

\author{
T. M. Tomyshyn, N. I. Reha, S. O. Yastremska \\ Khust District Hospital \\ I. Horbachevsky Ternopil State Medical University
}

\begin{abstract}
The paper reveals the morbidity structure and rate of students rate in the nursing school, the analysis and classification of diseases and also states that the main reason of the great variety of diseases is the low level of students' moving activity and the physical development and physical conditioning. The paper also presents the measures aimed at intensifying the educational process in the nursing school and reveals the prospects of introducing further educational health protection technologies of studies.
\end{abstract}

Вступ. Науково-технічний прогрес, досягнення комп'ютерної техніки стали мимовільною причиною загострення загальнолюдської проблеми гіподинамії, а особливо погіршення рівня здоров'я людей. Суспільство страждає від безлічі різноманітних хвороб, причому кількість хворих, на жаль, не зменшується, а навпаки зростає. Особливу групу серед молоді становлять студенти. В останні роки активізувалася увага до здорового способу життя студентів. Це пов'язано з інтересом суспільства до стану здоров'я фахівців, яких випускає вища школа, зростанням захворюваності в процесі професійної підготовки, наступним зниженням працездатності [1, 8, 9]. Проблему охорони здоров'я студентів вивчено недостатньо. Цьому потенційно найціннішому трудовому ресурсу суспільства на сьогодні не приділяють належної соціальної уваги, особливо за умов економічної кризи.

(c) Т. М. Томишин, Н. І. Рега, С. О. Ястремська, 2017
Встановлено, що на здоров'я людини впливає ряд факторів: стан довкілля, спадковість, система охорони здоров'я, спосіб життя людини. На даний час накопичений науковий матеріал, що доводить безпосередній вплив цілого ряду факторів навколишнього середовища [2]. Питанням збереження та зміцнення здоров'я займається система охорони здоров'я. До їі функцій відносять професійну діагностику захворювань, висококваліфіковане лікування хворих, ефективність лікарських препаратів, профілактичну роботу лікарів щодо попередження захворювань. Встановлено, що здоровий спосіб життя є важливим фактором формування і зміцнення здоров'я студентської молоді. Найактивнішими компонентами здорового способу життя виступають: раціональна праця студентів, раціональне харчування, раціональна рухова активність, загартування, особиста гігієна, відмова від шкідливих звичок [3].

4 ISSN 2411-1597. МЕДСЕСТРИНСТВО. 2017. № 3 
Сьогодні назріла необхідність у розробці сучасної системи контролю за фізичним станом студентської молоді, яка 6 відповідала вимогам сучасності. Вивчення стану здоров'я студентської молоді як частини суспільства має важливе значення для створення системи для управління цим процесом.

Одним із пріоритетних напрямів освіти в Україні $\epsilon$ збереження та зміцнення здоров'я студентської молоді, тому основною метою навчально-виховного процесу у вузі $є$ формування свідомого ставлення до власного здоров'я $[4,5]$.

Виникнення вже в молодому віці серцево-судинних захворювань, розладів роботи органів травлення, порушень мозкового кровообігу, онкологічнихуражень, ендокринної патології та інших хвороб диктує необхідність вивчення особливостей і причин розвитку захворюваності та формування профілактичних заходів із широким їх застосуванням ще в преморбідному періоді $[6,7]$.

Особливу групу серед молоді становлять студенти. На даний час спостерігають збільшення кількості студентів вищих навчальних закладів, які належать до спеціальних медичних груп [10]. Таку тенденцію спостерігають на фоні низького рівня фізичної підготовленості студентів, послаблення функцій нервової системи впродовж навчання та у період сесії, що негативно впливає на формування здоров'я майбутніх фахівців [1, 10-13].

Основна частина. Враховуючи вищевикладене, метою дослідження було визначення рівня захворюваності та інвалідності студентів Закарпатського базового державного медичного коледжу та надання рекомендації щодо зміцнення здоров'я студентів.
Дослідження було проведено на базі Закарпатського базового державного медичного коледжу протягом 2011-2015 рр., в якому брали участь студенти різних спеціальностей, які пройшли медичний огляд.

Обстежено 3345 студентів Закарпатського базового державного медичного коледжу за період з 2011 до 2015 рр.

Динаміку кількості студентів у Закарпатському базовому державному медичному коледжі за 2011-2015 рр. наведено на рисунку 1.

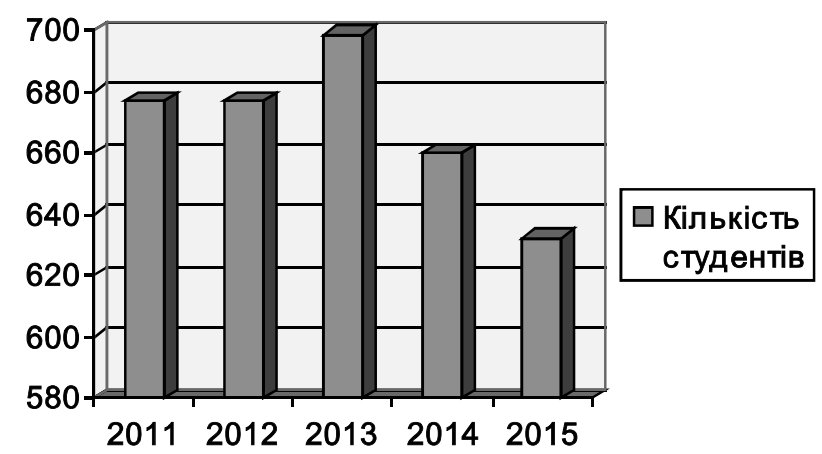

PUс. 1. Динаміка кількості студентів у Закарпатському базовому державному медичному коледжі за 2011-2015 pp.

Як видно з рисунка 1, кількість студентів за кожний досліджуваний рік була приблизно одинаковою, хоча за останні два роки спостерігають тенденцію до незначного зниження числа студентів.

Були проаналізовані основні медичні документи (амбулаторні картки, медичні довідки та статистичні показники обстеження студентів). Отримані результати проаналізовано за кількістю, роками та структурою захворюваності. Отримані дані наведено в таблиці 1.

Таблиця 1. Рівень та структура захворюваності в Закарпатському базовому державному медичному коледжі за 2011-2015 рр.

\begin{tabular}{|c|c|c|c|c|c|c|}
\hline \multirow{4}{*}{$\begin{array}{c}\text { № } \\
\text { за/п }\end{array}$} & \multirow{4}{*}{ Структура захворюваності } & \multicolumn{5}{|c|}{ Навчальний рік } \\
\hline & & 2011 & 2012 & 2013 & 2014 & 2015 \\
\hline & & \multicolumn{5}{|c|}{ кількість студентів } \\
\hline & & 677 & 677 & 699 & 660 & 632 \\
\hline \multirow[t]{4}{*}{1} & $\begin{array}{l}\text { Всього випадків інфекційних } \\
\text { захворювань: }\end{array}$ & 3 & 1 & 3 & 2 & 2 \\
\hline & - у т. ч. гострих кишкових інфекцій & 1 & - & 1 & - & - \\
\hline & $\begin{array}{l}\text { - у т. ч. інфекцій, які передаються повіт- } \\
\text { ряно-крапельним шляхом }\end{array}$ & 2 & 1 & 1 & 2 & 2 \\
\hline & - у т. ч. вірусний гепатит & - & - & 1 & - & - \\
\hline \multirow[t]{2}{*}{2} & На «Д» обліку всього: & 118 & 117 & 121 & 115 & 95 \\
\hline & -у т. ч. хронічний тонзиліт & 10 & 11 & 9 & 10 & 8 \\
\hline \multirow[t]{2}{*}{3} & Ревматизм - всього: & 5 & 5 & 6 & 6 & 4 \\
\hline & - у т. ч. із вадами серця & 1 & - & - & - & - \\
\hline 4 & Функціональні захворювання ССС & 22 & 30 & 35 & 33 & 29 \\
\hline
\end{tabular}


Продовження табл. 1

\begin{tabular}{|c|c|c|c|c|c|c|}
\hline \multirow{4}{*}{$\begin{array}{c}\text { № } \\
\text { за/ח }\end{array}$} & \multirow{4}{*}{ Структура захворюваності } & \multicolumn{5}{|c|}{ Навчальний рік } \\
\hline & & 2011 & 2012 & 2013 & 2014 & 2015 \\
\hline & & \multicolumn{5}{|c|}{ кількість студентів } \\
\hline & & 677 & 677 & 699 & 660 & 632 \\
\hline \multirow[t]{3}{*}{5} & Захворювання НС & 2 & 3 & 2 & 3 & 2 \\
\hline & -у т. ч. ДЦП & 2 & 3 & 2 & 3 & 2 \\
\hline & -у т. ч. енурез & - & - & - & - & - \\
\hline \multirow[t]{2}{*}{6} & Загальні захворювання органів зору: & 17 & 12 & 15 & 14 & 12 \\
\hline & - короткозорість & 17 & 12 & 15 & 14 & 12 \\
\hline \multirow[t]{2}{*}{7} & Загальні захворювання органів слуху: & 1 & 1 & 1 & 1 & 1 \\
\hline & -у т. ч. зниження слуху & 1 & 1 & 1 & 1 & 1 \\
\hline \multirow[t]{4}{*}{8} & Психічні розлади: & - & - & - & - & - \\
\hline & -у т. ч. олігофренія & - & - & - & - & - \\
\hline & Тубвіраж & - & - & - & - & - \\
\hline & Тубінтоксикація & - & - & - & - & - \\
\hline \multirow[t]{3}{*}{9} & ХНзл: & 8 & 7 & 6 & 5 & 2 \\
\hline & -у т. ч. хронічний бронхіт & 6 & 5 & 4 & 3 & - \\
\hline & -у т. ч. бронхіальна астма & 2 & 2 & 2 & 2 & 2 \\
\hline \multirow[t]{4}{*}{10} & Захворювання органів травлення: & 16 & 18 & 15 & 15 & 12 \\
\hline & - у т. ч. хронічний гастродуоденіт & 6 & 7 & 6 & 5 & 5 \\
\hline & -у т. ч. хронічний гепатит & - & - & - & - & - \\
\hline & - у т. ч. запальні захворювання ЖВШ & 10 & 11 & 9 & 10 & 7 \\
\hline \multirow[t]{3}{*}{11} & Захворювання нирок: & 6 & 6 & 5 & 5 & 4 \\
\hline & - у т. ч. хронічний пієлонефрит & 6 & 6 & 5 & 5 & 4 \\
\hline & -у т. ч. хронічний гломерулонефрит & - & - & - & - & - \\
\hline \multirow[t]{3}{*}{12} & Ендокринологічні захворювання: & 20 & 15 & 18 & 17 & 16 \\
\hline & -у т. ч. цукровий діабет & 3 & 2 & 2 & 2 & 3 \\
\hline & - у т. ч. гіперплазія щитоподібної залози & 17 & 13 & 16 & 15 & 13 \\
\hline \multirow[t]{2}{*}{13} & Ортопедична патологія: & 4 & 3 & 2 & 1 & 1 \\
\hline & -у т. ч. сколіоз & 4 & 3 & 2 & 1 & 1 \\
\hline \multirow[t]{3}{*}{14} & Захворювання шкіри: & - & - & - & - & - \\
\hline & -у т. ч. нейродерміти & - & - & - & - & - \\
\hline & -у т. ч. атопічний дерматит & - & - & - & - & - \\
\hline \multirow[t]{3}{*}{15} & Вроджені вади: & 6 & 6 & 7 & 5 & 4 \\
\hline & - у т. ч. вроджені вади серця & 2 & 3 & 3 & 2 & 1 \\
\hline & - у т. ч. вроджені вади КС & 4 & 3 & 4 & 3 & 3 \\
\hline 16 & Інваліди & 13 & 12 & 14 & 18 & 13 \\
\hline
\end{tabular}

Динаміку кількості студентів-інвалідів у Закарпатському базовому державному медичному коледжі за 2011-2015 рр. наведено на рисунках 2 та 3, а також у таблиці 2.

Як видно з рисунків 2 та 3, а також таблиці 2, кількість студентів-інвалідів була приблизно одинаковою за всі досліджувані роки. Тому число студентів-інвалідів є стабільним і може відображати кількість молодих осіб з інвалідністю у певних вікових групах у регіоні.

Відповідно до даних амбулаторних карток студентів та випадків тимчасової непрацездатності проаналі- зовано кількість випадків інфекційних захворювань серед студентів та їх нозологічну структуру.

Динаміку кількості випадків інфекційних захворювань серед студентів у Закарпатському базовому державному медичному коледжі за 2011-2015 рр. наведено на рисунках 4 та 5.

Як ілюструє рисунок 4, загальна кількість випадків інфекційних захворювань серед студентів знизилась за останні два роки, що може свідчити про покращення профілактичних заходів виникнення гострих інфекційних захворювань. 


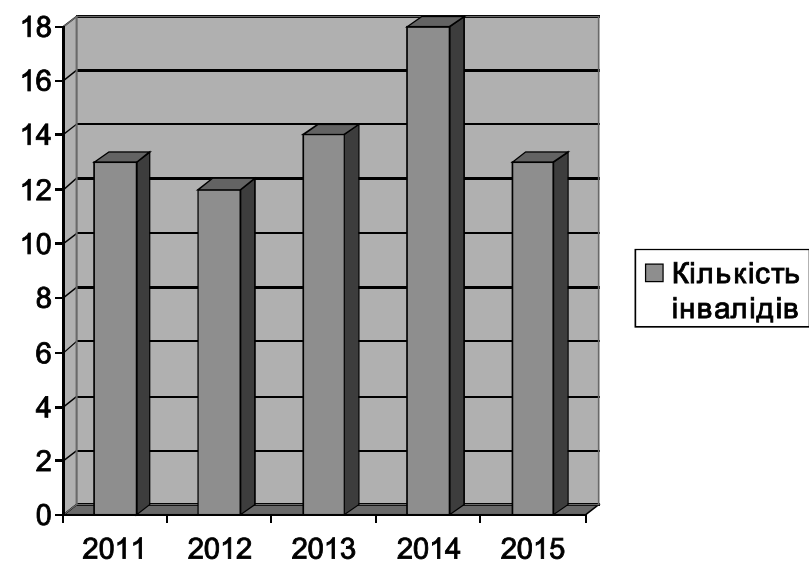

Рис. 2. Динаміка кількості студентів-інвалідів у Закарпатському базовому державному медичному коледжі за 2011-2015 рр. (абсолютні числа).

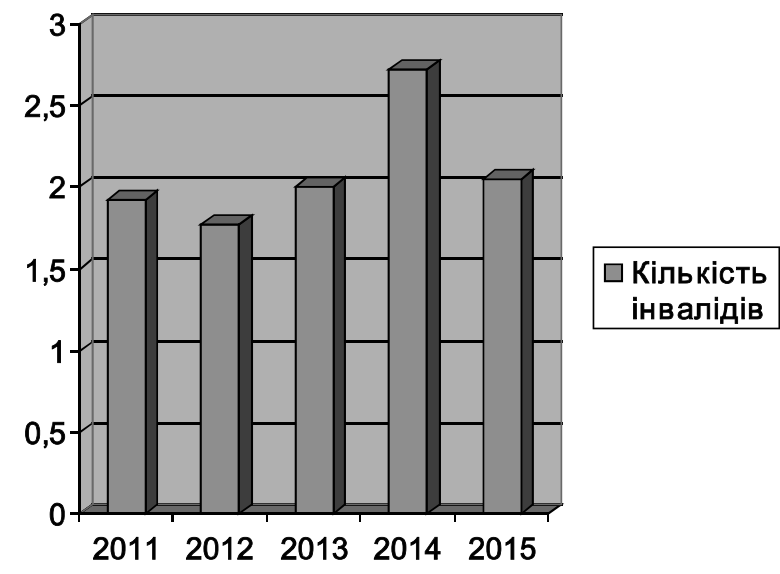

Рис. 3. Динаміка відносної кількості студентівінвалідів у Закарпатському базовому державному медичному коледжі за 2011-2015 рр.

Таблиця 2. Динаміка кількості студентів-інвалідів у Закарпатському базовому державному медичному коледжі за 2011-2015 рр.

\begin{tabular}{|l|c|c|c|c|c|}
\hline \multicolumn{1}{|c|}{ Роки } & 2011 & 2012 & 2013 & 2014 & 2015 \\
\hline Кількість студентів & 677 & 677 & 699 & 660 & 632 \\
\hline Кількість інвалідів & 13 & 12 & 14 & 18 & 13 \\
\hline Відсоток інвалідів & 1,92 & 1,77 & 2,00 & 2,72 & 2,05 \\
\hline
\end{tabular}

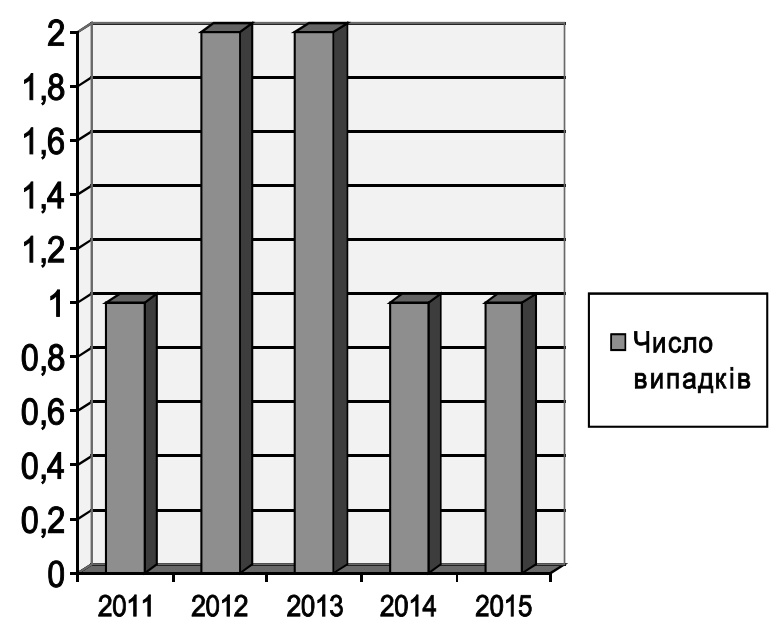

Рис. 4. Динаміка загальної кількості випадків інфекційних захворювань серед студентів у Закарпатському базовому державному медичному коледжі за 2011-2015 рр.

Як видно з рисунка 5, за останні два роки, поряд зі зниженням загальної кількості випадків інфекційних захворювань, в їх структурі практично зникли захворювання з групи кишкових інфекцій, ут. ч. вірусні гепатити. Дані результати можуть свідчити про покращення профілактичних заходів виникнення інфекційних захворювань 3 фекально-оральним механізмом передачі.

Про істинний стан здоров'я студентів свідчить число їх із наявністю хронічних захворювань, з приводу яких студенти перебувають на диспансерному обліку. Варто зазначити, що ці захворювання вима-

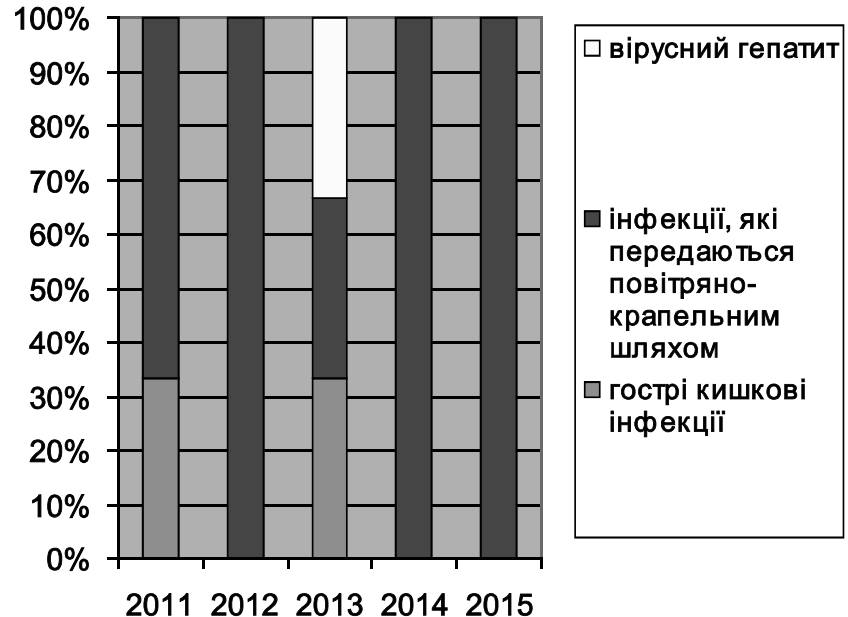

Рис. 5. Структура випадків інфекційних захворювань серед студентів у Закарпатському базовому державному медичному коледжі за 2011-2015 pp.

гають постійного спостереження і лікування, а також переведення студентів до спеціальних груп заняття фізичною культурою.

Динаміку кількості диспансерних хворих серед студентів у Закарпатському базовому державному медичному коледжі за 2011-2015 рр. наведено на рисунках 6 та 7 і таблиці 3.

Як видно із наведених даних, за останній рік накреслилася тенденція до зниження питомої частки диспансерних хворих серед студентів, що може свідчити про деяке покращення стану здоров'я студентів-медиків та 


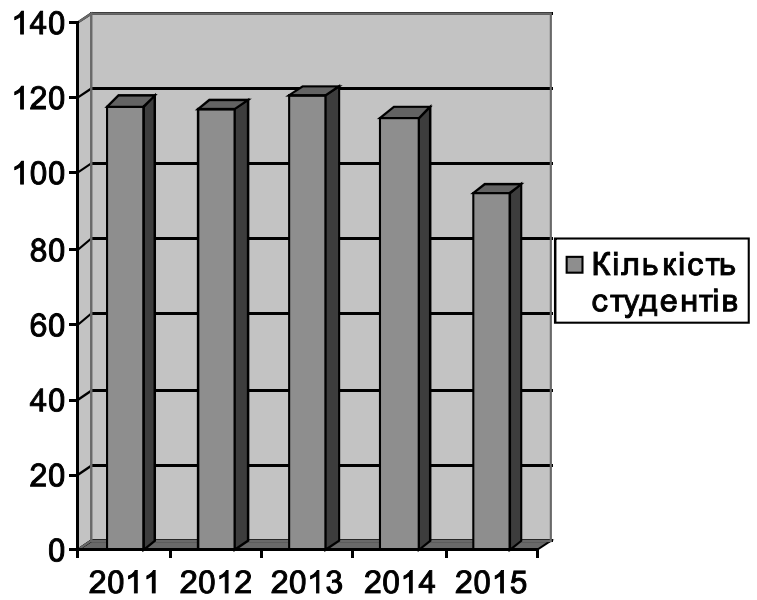

Рис. 6. Динаміка кількості диспансерних хворих серед студентів у Закарпатському базовому державному медичному коледжі за 2011-2015 рр. (абсолютні числа).

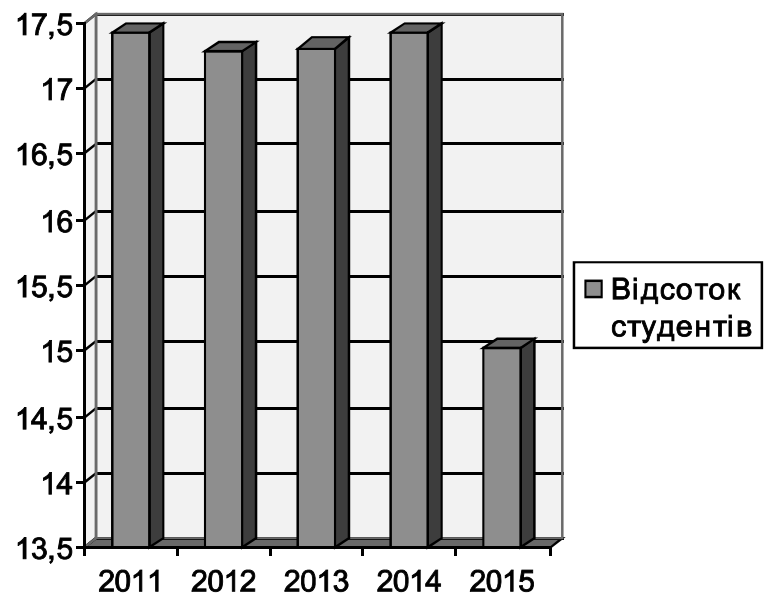

Рис. 7. Динаміка відносної кількості диспансерних хворих серед студентів у Закарпатському базовому державному медичному коледжі за 2011-2015 рр.

Таблиця 3. Динаміка кількості диспансерних хворих серед студентів у Закарпатському базовому державному медичному коледжі за 2011-2015 рр.

\begin{tabular}{|l|c|c|c|c|c|}
\hline \multicolumn{1}{|c|}{ Роки } & 2011 & 2012 & 2013 & 2014 & 2015 \\
\hline Кількість студентів & 677 & 677 & 699 & 660 & 632 \\
\hline Кількість диспансерних хворих & 118 & 117 & 121 & 115 & 95 \\
\hline Відсоток диспансерних хворих & 17,42 & 17,28 & 17,31 & 17,42 & 15,03 \\
\hline
\end{tabular}

про ефективність сучасних здоров'язберігаючих технологій, які використовують в освітньому процесі в Закарпатському базовому державному медичному коледжі.

Однак, за період спостереження значна питома частка студентів-медиків (від 17,42 до 15,03 \% від загального числа досліджуваного контингенту), була зарахована за результатами диспансеризації до групи хронічних хворих, які потребують постійного спостереження та лікування.

Структурний розподіл на диспансерні групи статистично не відрізняється від аналогічного розподілу у випускників загальноосвітніх середніх шкіл, що в черговий раз доводить потребу в комплексному та послідовному шляху вирішення проблеми зміцнення та збереження здоров'я молоді.

Найнижча захворюваність (як за кількістю випадків, так і за кількістю днів непрацездатності) спостерігалась у 2015 р., а найвища - у 2013.

Найчастіше хворіли студенти-першокурсники. Це можна пояснити насамперед тим, що студенти I курсу ще цілком не адаптувались до нових умов життя. У них з'явились нові форми навчання: лекції, семінари, лабораторні заняття, колоквіуми, заліки, що вимагають певних навичок.

Окрім того, все це проходило на фоні іншого способу життя, відсутності поряд батьків, зміни побутових умов, більших розумових та емоційних навантажень, що призвело до порушення функціонування захисних компенсаторних функцій організму й виникнення гострих захворювань або загострення хронічних.

За окремими нозологіями у студентів коледжу перше місце посідають функціональні захворювання ССС (від 22 до 25 випадків). У більшості випадків було діагностовано вегетативну дисфункцію.

Друге місце займають хвороби ендокринної системи (від 16 до 20 випадків).

Структуру захворюваності органів ендокринної системи представлено таким чином: цукровий діабет від 2 до 3 випадків, гіперплазія щитоподібної залози (що має ознаки ендемічного походження) - від 13 до 17 випадків.

На третьому місці захворювання органів травлення (від 22 до 25 випадків).

Структуру захворюваності органів травлення представлено таким чином: хронічний гастродуоденіт від 2 до 3 випадків, запальні захворювання ЖВШ - від 7 до 11 випадків.

Серед інших захворювань у ці роки часто спостерігались:

- хронічний тонзиліт;

- ревматизм;

- короткозорість; 
- хронічний бронхіт;

- бронхіальна астма;

- хронічний пієлонефрит;

- сколіоз;

- вроджені вади серця;

- вроджені вади кісткової системи.

Будь-якої залежності у частоті й порядку виникнення цих захворювань не виявлено.

Із метою раннього виявлення захворювань у студентів лікувально-профілактичні заклади зобов'язані щорічно проводити обов'язкові медичні огляди. Після встановлення діагнозу потрібно пояснити пацієнтові в доступній формі стан його здоров'я, прогноз можливого розвитку захворювання, місце й порядок лікування.

Висновки. Результати проведеного дослідження переконливо доводять, що:

1. За результатами диспансеризації 15,03 \% від загального числа здобувачів медичної освіти, зараховано до диспансерної групи - хворих на хронічну патологію осіб, які потребують лікування.

\section{СПИСОК ЛІТЕРАТУРИ}

1. Вовченко І. І. Стан здоров'я студентів коледжів / І. І. Вовченко, Н. Ц. Тунік, Т. В. Стаднік // Проблеми фізичного виховання і спорту. - 2010. - № 1. - С. 33-35.

2. Физическая культура : учебное пособие. - Ростов-наДону : Феникс, 2002. - 384 с. - (Серия «Учебники, учебные пособия»).

3. Раевский Р. Т. Здоровый образ жизни специалиста / Р. Т. Раевский. - Одесса : ОНПУ, 2000. - 52 с.

4. Драчук А. І. Динаміка стану здоров'я студентів гуманітарних вищих закладів освіти / А. І. Драчук // Педагогіка, психологія та медико-біологічні проблеми фізичного виховання і спорту : збірник наукових праць. - Харків : ХДАДМ (ХХПІ), 2002. - № 22. - С. 23-28.

5. Євстратов П. І. Рівень здоров'я в залежності від рухової активності студентів / П. І. Євстратов // Буковинський науковий вісник. - 2005. - С. 209-211.

6. Вольєва Н. П. Захворюваність студентів вищих навчальних закладів, які належать до спеціальних медичних груп / Н. П. Вольєва, А. С. Вовканич // Спортивна наука України. - 2011. - № 6.

7. Москаленко В. Ф. Здоров'я населення і проблеми охорони здоров'я у світі та Європі: стан питання та тенденції (огляд) [текст] / В. Ф. Москаленко // Охорона здоров'я України. - 2003. - № 4. - С. 5-8.

8. Мосієнко Г. П. Клінічна характеристика загальносоматичних порушень та заходи їх профілактики у юнаків з різними умовами проживання [текст] : автореф. дис. на здобуття наук. ступеня канд. мед. наук : 14.01.02 / Г. П. Мосієнко. - К., 2003. - 20 с.
2. 3-поміж усіх хронічних нозологій, що потребують лікування, у студентів-медиків найчастіше діагностують хвороби ССС, органів травлення та ендокринної системи.

3. На нашу думку, наявна необхідність в опрацюванні та запровадженні організаційно-функціональної моделі попередження впливу негативно діючих факторів ризику на стан здоров'я студентів-медиків як основи управління станом здоров'я майбутніх медичних працівників. Враховуючи достатньо складну і напружену соціально-економічну ситуацію в Україні, зниження економічного добробуту населення, невідповідність умов навчального навантаження віковим можливостям студентства, питання охорони ізміцнення здоров'я $\epsilon$ найважливішою складовою освітнього процесу в медичних коледжах. Водночас, як свідчать численні дослідження, залишається досить низькою реалізація оздоровчого (здоров'язберігаючого) потенціалу освітнього закладу. Одним із можливих способів розв'язання цієї проблеми є розробка і впровадження технологій здоров'язбереження як компонента професійної підготовки студентів.

9. Нагорна А. М. Стан здоров'я населення України / А. М. Нагорна // Краєзнавство. Географія. Туризм. - 2004. № 2. - C. 4-13.

10. Дубогай О. Д. Фактори, які визначають ефективність фізичного виховання студентів спеціальної медичної групи / О. Д. Дубогай // Актуальні проблеми розвитку руху «Спорт для всіх» у контексті європейської інтеграції України : матеріали наук.-практ. конф. - Тернопіль, 2004. С. 370-374.

11. Васильченко В. Науково-методичні основи використання тесту Купера на учбових заняттях з плавання / В. Васильченко // Фізична культура, спорт та здоров'я нації - нова епоха, нова генерація : матеріали Всеукраїнської наук.-практ. конф. - Миколаїв, 2002. C. 117-119.

12. Вовченко І. І. Фізична підготовленість студентів медичного коледжу / І. І. Вовченко, Т. В. Стаднік // Педагогіка, психологія та медико-біологічні проблеми фізичного виховання і спорту : наукова монографія за ред. проф. С. С. Єрмакова. - Харків : ХДАДМ (ХХПІ), 2008. - № 8. C. 39-41.

13. Волков В. Л. Спрямованість засобів тренувального впливу в процесі фізичної підготовки першокурсників гуманітарних факультетів : матеріали 10 Всеукраїнської конференції аспірантів галузі фізичної культури і спорту, Львів, 2006. - С. 78.

Отримано 22.06.17 